\title{
WHAT TEACHERS THINK ABOUT ASSESSMENT AND HOW IT INFLUENCES THEIR CLASSROOM-BASED ASSESSMENT PRACTICES - THE RESULTS OF A GLOBAL SURVEY
}

\author{
Susan Sheehan* \\ School of Education and Professional Development \\ University of Huddersfield, Queensgate, Huddersfield
}

Received 26 February 2020

Revised 16 May 2020; Accepted 24 July 2020

\begin{abstract}
This paper considers teachers' attitudes to assessment. The attitudes were explored through Borg's (2015) Language Teacher Cognition Framework. A mixed-methods approach of questionnaire and interview was adopted. The online survey was completed by English language teachers working in 57 different countries worldwide. The questionnaire was divided into 3 sections. The first section included questions which related to the participants' experiences of assessment at school. The second section explored the participants' assessment training experiences both in their initial teaching training and in any professional development sessions they had attended. The third and final section explored the participants' assessment practices and their beliefs about assessment. These three sections are based on the Language Teacher Cognition Framework. The interviews were conducted to explore the reasoning behind the responses given to the questionnaire. The framework also informed the data analysis process. Classroom experiences and professional development sessions were found to have the most influence on the teachers' attitudes to assessment. The participants were influenced by their experiences of assessment at school as they choose to avoid replicating the assessment practices which had been used when they were being assessed.
\end{abstract}

Keywords: Assessment, Teacher Cognition, Questionnaire

\section{Introduction}

This paper explores language teacher cognition and assessment. We investigated teachers' attitudes to assessment and how assessment influences their classroom-based assessment practices. We engaged with teachers of English as a foreign language (EFL) from around the world through an online questionnaire and follow-up interviews. The

* Tel.:44 1484478144

Mail: S.Sheehan@hud.ac.uk. impetus for the project described in this paper was the puzzling results of a previous project (Berry, Sheehan and Munro, 2019) which had focussed on Language Assessment Literacy (LAL). We conducted a series of classroom observations which focussed on classroombased assessment practices. We observed the teachers successfully deploying a range of assessment techniques in the classroom. When taking part in post-observation interviews those teachers all talked negatively about assessment and considered the observed assessment 
activities to be part of their teaching practices. This led us to consider that the teachers had a fundamentally different understanding of assessment than the one we had developed through our reading of the LAL literature. We started to wonder if exploring the issue of assessment through the prism of teacher cognition would improve our understanding of classroom-based assessment practices

Much of the research into teachers' assessment practices has taken the approach of considering assessment to be a static body of knowledge which teachers have not mastered due to a lack of training in the topic or a lack of interest in the topic (Vogt and Tsagari, 2014). Our project, in contrast, explored assessment as a multi-layered and complex phenomenon which requires teachers to operate as both assessor and teacher (Scarino, 2013). Teachers have dual roles, and, at times, these roles can seem to be in conflict. For example, as an assessor a teacher may find a student's performance to be poor, but the teaching role could view the same performance as the starting point for a teaching intervention. It may be the case that the role of teacher is, perhaps unsurprisingly, more important to the teacher (Sheehan and Munro, 2017). Looney, Cumming, van Der Kleij, and Harris (2018) have also considered that teachers can have mixed feelings about assessment. These sentiments can be can be based on their feelings or experiences but also depend on their view of their role as teacher and if they are being asked or forced to engage with assessment activities which they feel are not part of their role as teacher.

Negative experiences of assessment have often been used as an explanation for poor levels of LAL. For example, $\mathrm{Xu}$ and Brown (2016) conducted an extensive review of studies which investigated assessment literacy. One of the conclusions which they drew from this review is that teachers' negative experiences of assessment impede their development of LAL. DeLuca, Chavez, Bellara and Cao (2013) are concerned that teachers have been adversely affected by their negative experiences of summative assessment. This leads them to view assessment negatively, but they also replicate the assessment types they were exposed to as they do not have alternative paradigms on which to draw. Ell, Hill and Grudnoff (2012) also raise the concern that teachers will reproduce the assessment practices they themselves experienced. Graham (2005) argues that teacher candidates in the US equated assessment with a test and that misapprehension was based on their experiences as students. This barrier to LAL has been encapsulated as teachers testing as they, themselves, were tested (Vogt and Tsagari, 2014).

Survey, to gather data about teachers' level of assessment literacy, has been a commonly used research strategy in both the fields of general education and English Language Teaching (ELT). The surveys, which have been conducted around the world with teachers working in a variety of educational settings, (e.g. Brookhart, 2011, Fulcher 2012, Hasselgreen, Carlsen and Helness. 2004, Mertler and Campbell, 2005) have generally presented teachers with items which relate to assessment and the teachers are asked if they are familiar with them. Some surveys further enquire if the teachers would like to receive training in those items with which the teachers felt themselves to be unfamiliar. Many of these studies have pointed to deficits in teacher knowledge about assessment. A limitation of survey research is that participants can only respond to the questions asked of them. The teachers may have been knowledgeable about other areas of assessment which had not been included in 
the surveys. Furthermore, the teachers who responded to surveys with requests for further training may have considered it as being professional to do so. The teachers were keen to expand all areas of their practice and the requests were an expression of interest rather than a cry for help.

As has been discussed above negative experiences of assessment have often been used as an explanation for low levels of LAL. In the literature relating to teacher education classroom experiences as children have been considered as having a strong influence on classroom practice. For example, Beijard, Meijer and Verloop (2004) suggest that teacher training is less influential on classroom practices than experiences at school. Thus, all childhood classroom experiences are influential on classroom practice and those which relate to assessment seem to be strongly influential. It may be the case the aspects of teacher training which relate to assessment do not influence classroom practices as childhood experiences of assessment are highly influential on classroom practice.

\section{Materials and Methods}

The following research questions (RQs) informed the project:

1. How do teachers develop their identity as assessors?

2. What role do teachers experiences of assessment, both in their own schooling, and as teachers, play in the development of their assessment practices?

3. How do teachers put their assessment 'credo' into practice?

The three research questions were developed following completion of the literature review. RQ1 was developed from
Looney et al's (2018) model of Teacher Assessment Identity (TAI). Looney et al (2018: 14) state: “... we propose a dynamic and interactive assessment identity constituted by beliefs, feelings, knowledge and skills." RQ2 reflects Borg's (2015) framework for language teacher cognition. This framework will be discussed in Section 3 of this paper. The term credo in the third research question was inspired by Yin's (2010) study which looked at how teachers made assessment related decisions both in the classroom and when writing lesson plans. He argued that teachers had a set of beliefs or 'credo' which underpinned all decisions and practice. The data presented in this paper mainly refer to RQ2. Further details of the whole project and the data collected for the first and third RQ can be found in Sheehan and Munro (2019).

\section{Mixed-methods strategy.}

A mixed-methods approach (Cohen, Manion, Morrison, \& Bell, 2011; 2013) was adopted. Data were collected through questionnaire and follow-up interview. The questionnaire had been inspired by Borg and Burns' (2008) survey of teacher beliefs about teaching grammar. The interviews were conducted to explore the reasoning behind the responses given to the questionnaire. The questionnaire was divided into 3 sections. The first section included questions which related to the participants' experiences of assessment at school. The second section explored the participants' assessment training experiences both in their initial teaching training and in any professional development sessions they had attended. The third and final section explored the participants' assessment practices and their beliefs about assessment. The questionnaire started with biographical questions such as years of teaching experience, qualifications and the type of institution in which they taught 
most often. We recognise that many teachers work for a variety of different institutions both in the public and private sectors. Following Borg and Burns (2008) we did not ask the participants if they considered themselves to be own language speakers of English or not as these distinctions seem to be reductive. The questions in the main section of the questionnaire were 5-point Likert scale. There was one open response question to allow participants to make any comment they wanted to. As we planned to conduct interviews, we did not include open response items on the questionnaire. At the end of the questionnaire we asked participants who were willing to be interviewed to leave their email address. The online questionnaire was promoted by the British Council and through the professional networks of the researchers. The interviews were conducted using Zoom. The semi-structured interviews were also based on the three identified aspects of Borg's (2015) framework.

Below is a table which summarises the participant numbers and their locations.

Table 1. Participant numbers and their locations

\begin{tabular}{ccc}
\hline Data Collection Stage & Participants & Location \\
\hline Questionnaire & 261 participants & $\begin{array}{c}\text { Worldwide, with participants } \\
\text { from 57 different countries }\end{array}$ \\
\hline Interviews & 10 interviews & Worldwide \\
\hline
\end{tabular}

We used the following definition of teacher by Vogt and Tsagari: "Someone who is a practising EFL teacher who has undergone regular training to teach English as a foreign language at state or private tertiary institutions, colleges or schools." (2014:377). Our participants taught all ages and levels of students from young learners to adults, including general English and English for Specific Purposes. Responses were obtained from five different continents. 240 participants stated they worked in countries where English was taught as a foreign language. The remaining 21 participants worked in countries where English is taught as second language. Of this group the majority (17) were working in the UK. There was great variation in the language policies of the countries where the participants worked. One of the limitations of conducting research on a global scale is that the opportunities for exploring national language policies are, necessarily, limited. Some countries and regions were more represented such as India and South America which may reflect British Council activity in those countries. 32 respondents were from Vietnam. The sample was essentially selfselecting. The use of the word assessment in the questionnaire title may have been offputting for some teachers so the respondents could be those teachers with a special interest in assessment. The participants could be described as being experienced as $51.3 \%$ had 15 years plus experience as a teacher. They could also be described as well-qualified as $34.1 \%$ had master's qualifications and $7.3 \%$ held a doctorate. This final figure may reflect use of the International Association of Teachers of English as a Foreign Language (IATEFL) research special interest group as one of the promotion channels for the questionnaire. A special interest group which focusses on research might be expected to have a number of members who hold doctorates. $48.7 \%$ of the participants stated they worked in state sector most often. It may well be the case that several participants worked in a variety of different sectors. Secondary/high school was 
the most common workplace with $32.2 \%$ of participants stating they worked most often in this type of institution.

The questionnaire data were analysed using descriptive statistics. The interview data were analysed thematically. The themes were developed from Borg's (2015) Language Teacher Cognition Framework. This framework is discussed below.

\section{Theory}

\section{Language Teacher Cognition}

Borg (2015:321) defines language teacher cognition as: “... an inclusive term referring to the complex practically-orientated, personalized, and context-sensitive networks of knowledge, thoughts and beliefs that language teachers draw on in their work." This definition highlights the complexity of the proposition and its multi-faceted nature. This framework was chosen because of the focus on language teachers. Borg (2015) highlights the ways in which language teaching differs from the teaching of subjects which means that other teacher cognition frameworks would not have been appropriate for this project. In addition, the framework considers teacher cognition to be context-sensitive. This is of special relevance to a project which focuses on assessment as the assessment policies of country, for example, the requirement to pass an English examination as part of college entry requirements can influence the classroom-based assessment practices.

The project drew on Borg's Language Teacher Cognition Framework. The framework includes: Schooling, Professional Coursework and Classroom Practices. These factors impact on language teacher cognition. The relationship between these factors and language teacher cognition is two-way. RQ2 was based on this framework.

\section{Results}

A key and unexpected finding was that $74.4 \%$ of participants stated they did not use the same techniques as their teachers used with them. The significance of this result will be discussed below. One of the interviewed teachers stated: "At school we never knew what was expected from us...the grades were shady you never knew why you got a three or a four." This person, and she was one among several, lamented the opaqueness of the marking system used at her school. She did not understand what she needed to do to gain high grades and she was not clear about the rationale behind the scores she was awarded. $51.3 \%$ of participants stated school assessment experiences influenced assessment practices. This could seem to contradict the previously stated finding. A review of the qualitative data may suggest that the two different findings are not, in fact, contradictory. The following interview quotations, selected from many which expressed similar views, may help to understand the situation better. One participant stated: "My experience taught me the things I should stop doing." Another participant said: "We just had tests we didn't get feedback." So, there is evidence to suggest that participants were actively seeking to avoid repeating the assessment practices which they had experienced as school children.

Few participants stated they had experienced assessment activities associated with assessment for learning such as self- or peer-assessment as children. The participants stated they used such activities regularly. For example, $66.8 \%$ of the questionnaire respondents stated they used self-assessment. One of interviewed teachers explained his use of peer assessment thus: "I use peer assessment all the time, the power relationship is more symmetrical, and they are more inclined talk to each other so that lowers the filter and all that. It encourages negotiation and clarification, 
encourages noticing and critical thinking, and it encourages a more student-centred approach." Nearly half $(48.5 \%)$ of the questionnaire respondents stated that they had not experienced self-assessment or similar activities when they were students themselves but stated that they used them as teachers. This is further support for the claim that the participants are not replicating the assessment practices which they themselves had experienced. It should also be noted that contextual factors can limit the range of assessment activities used in the classroom. One participant in Thailand stated: "I do my best to work with assessment for learning, they find it strange because the culture here is having tests."

$90.2 \%$ of participants stated they monitored students throughout the lesson. This could be considered an unsurprising finding. Assessment and teaching are intertwined or interwoven. One participant stated that it was classroom experience which helped her to understand the importance of assessment. She stated: "Everything starts with assessment - it took me a long time to learn this - we start thinking with good achievement and this is how assessment is part of planning, assessment is part of teaching, so in thinking about how I'm going to assess I decided how to teach and plan a topic, how it will be assessed throughout the lessons...I cannot think about teaching without thinking about assessment." These findings suggest that classroom experiences as a teacher are highly influential on assessment practice and that assessment practices develop out of reflections on classroom practice. This further quotation exemplifies the influence of teaching practice on the development of assessment practices. One teacher stated: "At the beginning I reproduced what I was exposed to. It was only when I started having to explore different ideas I realised I could do something different."
While some participants mentioned experience as a key influence on the development of their assessment practices others highlighted the importance for them of attending Continuous Professional Development (CPD) courses. For example, a participant from Poland stated that a training course delivered by the Peace Corps had led her to change her assessment practices: "So I realised it wasn't the way to motivate students. I realised I was closing the loop." She completely changed her assessment practices after attending a training course on assessment for learning. She went on to explain that when she had used pen-and-paper tests with the students the dialogue stopped when the students had received their mark. When she used the assessment activities, which she had learnt on the course she was able to create more constructive dialogues with her students which developed over the whole academic year. Another participant stated: "I got to learn about formative assessment, so I started changing my way of assessment."

A further example of the importance of CPD course on the development of assessment practices relates to the introduction of Common European Framework of Reference (CEFR). Several participants indicated they had attended courses on the CEFR. One participant from Brazil stated: "I did a course on the CEFR - they encouraged the use of the portfolio, for selfevaluation and for us to evaluate them." This would seem to suggest the action-orientated approach to language learning and assessing as described in the CEFR has had an influence on classroom-based assessment practices through CPD courses.

Contextual factors were also influential on classroom-based assessment practices. In the interviews a number of teachers mentioned the difficulties of meeting parental expectations. A teacher in India stated that the parents demanded that she gave 
her students a mock test every week. Such a practice did not accord with her beliefs on assessment but she felt she was not in a position to refuse the request. This comment was made by a single teacher but illuminates the pressures some teachers are under. She stated: "Authorities can come and check your books or tests without warning - a colleague did receive criticism from the authorities." It would seem that some teachers are subject to severe scrutiny and face a heavy burden of accountability. Contextual factors should also be taken into consideration when reviewing the results of this project. The teachers who responded to the survey may be more proactive or they may have more favourable working conditions with associated provision of training and development opportunities. Thus, their experiences may not reflect those of teachers who are not able to engage with the British Council or who do not have the opportunity to participate in research projects.

\section{Discussion}

We had anticipated that assessment experiences as a language learner would be influential on teachers' assessment practices with teachers testing as they had been tested (Vogt and Tsagari, 2014, Xu and Brown, 2016, Ell, Hill and Grudnoff, 2012). However, the participant teachers made a conscious decision not to replicate these practices as they were aware of the shortcomings of pen-and-paper tests even though they had tended to score high marks on such tests. There is evidence to suggest that participants were actively seeking to avoid repeating the testing practices which they had experienced as school children.

The participants emphasised the importance of self- and peer-assessment activities in their classroom-based assessment activities. These findings echo those reported in our previous study of teacher assessment practices (Sheehan and
Munro, 2017). The teachers stated that such practices promoted a more holistic approach to language learning which encouraged leaners to focus on developing their level of language proficiency and not on test scores. This finding is in contrast with that of Graham (2005) who found that the participants in her study had a rather limited conception of assessments and tended to confuse tests for assessment. Few participants reported they had experienced self-assessment as students, so classroom teaching experience would seem to be highly influential on language teacher cognition.

Experiences in the classroom and participation in continuous professional development courses were found to be more influential in the development of teachers' assessment practices and beliefs that either their schooling or initial training qualifications. This finding would seem to suggest that Beijard et al's (2004) proposition that initial teacher training is not influential on classroom teaching practice is accurate. This project, however, did not find evidence to support the notion childhood classroom experiences were influential on teaching practice. Rather, this study found that CPD and time spent teaching in the classroom had the largest influence on teachers' classroombased assessment practices.

The use of Borg's language teacher cognition framework allowed us to explore the teachers' attitudes to assessment and how these influenced their classroom-based assessment practices in a nuanced way. The different parts of the framework and the bi-directional relationship between them helped us to tease out the different influences on classroom practice. The findings of this study are also in accord with Scarino's (2013) view of assessment as a multi-layered and complex phenomenon. In addition, the use of framework allowed us to explore the influence of contextual factors on assessment practices. These factors included 
parental pressures and on-the-spot inspections of teaching materials and tests.

This project, like all projects, has limitations which should be acknowledged. The sample was self-selecting and it may have attracted teachers with a particular interest in assessment. The survey was only available online so teachers without reliable internet access were excluded from the study. The questionnaire was promoted through a number of different channels such as British Council websites and Twitter. Teachers who do not engage with such channels were also excluded from the study. The project is based on self-report data and this might not accurately reflect classroom practice. It is a representation of what the teachers say they do in the classroom. The survey did attract respondents from around world so in one sense it can be considered to be a global survey. The number of participants, however, represents only a tiny fraction of the total number of EFL teachers in the world.

\section{Conclusions}

In sum, the teachers in this project do not appear to 'test as they were tested' (Vogt and Tsagari, 2014). Teaching experience and engagement with CPD activities are both highly influential on the development of classroombased assessment practices. The teachers promoted a holistic and student-centred approach to language teaching and learning. Assessment is a tool to support this approach. We found that teacher cognitions are most influenced by teaching experiences and training courses.

In terms of teacher education, we would make three recommendations. Firstly, teachers should be encouraged to reflect on their own experiences of assessment and reflect on how these have influenced their assessment practice. Secondly, teachertraining courses should focus more on classroom-based assessment activities.
Lastly, trainee-teachers' assessment practices should be discussed during feedback on teaching practice sessions.

\section{References}

Beijaard, D., Meijer, P. C., \& Verloop, N. (2004). Reconsidering research on teachers' professional identity. Teaching and Teacher Education, 20(2), 107-128. doi:10.1016/j.tate.2003.07.001

Berry, V., Sheehan, S., \& Munro, S. (2019). What does language assessment literacy mean to teachers? ELT Journal, 73(2), 113-123. doi:10.1093/elt/ccy05

Borg, S. (2006) Teacher cognition and language education: Research and practice. London: Continuum.

Borg, S. (2015). Teacher cognition and language education: Research and practice (1st ed.). London, England; New York: Bloomsbury Academic.

Borg, S and Burns, A. (2008). Integrating grammar in adult TESOL classrooms. Applied Linguistics 29(3), 456-482

Brookhart, S. M. (2011). Educational assessment knowledge and skills for teachers. Educational Measurement: Issues and Practice, 30(1), 3-12. doi:10.1111/j.1745-3992.2010.00195.x

Cohen, L., Manion, L., Morrison, K., \& Bell, R. (2011; 2013). Research methods in education (7th; Seventh; ed.). London; New York; Routledge. doi:10.4324/9780203720967

DeLuca, C., Chavez, T., Bellara, A., \& Cao, C. (2013). Pedagogies for preservice assessment education: Supporting teacher candidates' assessment literacy development. The Teacher Educator, 48(2), 128.

Ell, F., Hill, M., \& Grudnoff, L. (2012). Finding out more about teacher candidates' prior knowledge: Implications for teacher educators. Asia - Pacific Journal of Teacher Education, 40(1), 55.

Fulcher, G. (2012). Assessment Literacy for the Language Classroom. Language Assessment Quarterly 9(2), 113-132. doi:10.1080/15434303.2011.642041

Graham, P. (2005). Classroom-based assessment: Changing knowledge and practice through preservice teacher education. Teaching and Teacher Education, 21(6), 607-621. doi:10.1016/j.tate.2005.05.001

Hasselgreen, A., Carlsen, C. and Helness, H. (2004). European Survey of Language Testing and Assessment Needs. General Findings, On WWW at http://www.ealta.eu.org/resources.htm.

Looney, A, Cumming, J, van Der Kleij, F and Harris, K. (2018). Reconceptualising the role of teachers as assessors: teacher assessment identity. Assessment in Education: Principles, Policy \& Practice, 25(5), 442-467.

Mertler, C. A., Campbell, C. S. (2005, April). Measuring teachers' knowledge and application of classroom assessment concepts: Development of 
the Assessment Literacy Inventory. Paper presented at the annual meeting of the American Educational Research Association, Montreal, Quebec, Canada.

Scarino, A. (2013). Language assessment literacy as self-awareness: Understanding the role of interpretation in assessment and in teacher learning. Language Testing, 30(3), 309-327. doi:10.1177/0265532213480128

Sheehan, S and Munro, S. (2017). Assessment: attitudes, practices, needs. British Council: London

Sheehan, S and Munro, S. (2019). Classroom assessment: the development of teachers' cognitions. British Council: London
Vogt, K and Tsagari, D. (2014). Assessment Literacy of Foreign Language Teachers: Findings of a European Study. Language Assessment Quarterly, 11(4), 374402. doi:10.1080/15434303.2014.960046

$\mathrm{Xu}, \mathrm{Y}$ and Brown, G. (2016). Teacher assessment literacy in practice: A reconceptualization. Teaching and Teacher Education 58. doi:10.1016/j. tate.2016.05.010

Yin, M. (2010). Understanding Classroom Language Assessment Through Thinking Research. Language Assessment Quarterly, 7(2), 175-194. doi:10.1080/15434300903447736

\title{
THÁI ĐỘ CỦA GIÁO VIÊN VỀ ĐÁNH GIÁ VÀ ẢNH HƯỞNG CỦA THÁI Độ GIÁO VIÊN ĐỐI VỚI THỰC TIỄN ĐÁNH GIÁ TRÊN LỚP - KẾT QUẢ CỦA MỘT KHẢO SÁT TOÀN CẦU
}

\author{
Susan Sheehan \\ Khoa Giáo dục và Phát triển Chuyên môn \\ Đại học Huddersfield, Queensgate, Huddersfield
}

Tóm tắt: Bài viết này nghiên cứu thái độ của giáo viên đối với đánh giá. Thái độ của giáo viên đã được nghiên cứu thông qua “Khung nhận thức của giáo viên ngôn ngữ” của Borg (năm 2015). Nghiên cứu này áp dụng phương pháp nghiên cứu hỗn hợp sử dụng bảng câu hỏi và phỏng vấn. Một cuộc khảo sát trực tuyến đã được thực hiện với các giáo viên dạy tiếng Anh tại 57 quốc gia khác nhau trên toàn thế giới. Bảng câu hỏi được chia thành 3 phần. Phần thứ nhất bao gồm các câu hỏi liên quan đến kinh nghiệm đánh giá tại trường của những người tham gia nghiên cứu. Phần thứ hai tìm hiểu kinh nghiệm đào tạo đánh giá cả trong giảng dạy ban đầu và trong tất cả các khoá phát triển chuyên môn họ đã tham gia. Phần thứ ba và cũng là phần cuối cùng xem xét thực tiễn đánh giá của những người tham gia và quan điểm của họ về đánh giá. Ba phần này đều dựa trên lý thuyết "Khung nhận thức của giáo viên ngôn ngữ". Các bài phỏng vấn được thực hiện nhằm tìm hiểu lý do đằng sau các câu trả lời trong bảng câu hỏi. Quá trình phân tích dữ liệu cũng dựa trên khung lý thuyết. Kết quả nghiên cứu cho thấy kinh nghiệm giảng dạy trên lớp và các khóa phát triển chuyên môn có ảnh hưởng lớn nhất đến thái độ của giáo viên. Giáo viên bị ảnh hưởng bởi kinh nghiệm đánh giá của họ ở trường vì họ tránh lặp lại các phương pháp đánh giá đã được sử dụng để đánh giá họ.

Từ khóa: Đánh giá, nhận thức giáo viên, bảng câu hỏi 